\title{
Electromagnetic Catalytic Cracking Process of Vacuum Residue Using $\mathrm{Fe}_{2} \mathrm{O}_{3} / \mathrm{Al}_{2} \mathrm{O}_{3}$
}

\author{
Metta Wijayanti ${ }^{1 *}$, Sri Haryati ${ }^{1}$, Muhammad Djoni Bustan ${ }^{1}$ \\ ${ }^{1}$ Chemical Engineering Department, Postgraduated Program, Faculty of Engineering, Sriwijaya University \\ Jl Raya Inderalaya - Prabumulih Km. 32 Ogan Ilir (OI), 30622 \\ * corresponding author's email: djajashanta@yahoo.com
}

Article history

$\begin{array}{llll}\text { Received } & \text { Received in revised form } & \text { Accepted } & \text { Available online } \\ \text { 20 December 2019 } & \text { 30 March 2020 } & \text { 31 March 2020 } & \text { 31 March 2020 }\end{array}$

\begin{abstract}
Vacuum residue is well known as waste product from crude oil refinery. Need a further process to improve its quality. In this study, a catalytic cracking process of vacuum residue in electromagnetic field was investigated using $\mathrm{Fe}_{2} \mathrm{O}_{3} / \mathrm{Al}_{2} \mathrm{O}_{3}$ as catalyst. The optimization process is conducted by combination vacuum residue and catalyst in the ratios of 1:5, 1:6, 1:7, 1:8, and 1:9 in $75 \mathrm{~min}$ of reaction time, $400^{\circ} \mathrm{C}$ and $10 \mathrm{~A}$ applied current. Liquid product is analyzed using gas chromatography mass spectrometry (GCMS). The result showed the formation of p-xylene, paraffin, and naphthalene were detected $11.38 \%$ in the retention time of $4.3 \mathrm{~min}, 1.04 \%$ in the retention time of $7.76 \mathrm{~min}$, and $3.28 \%$ in the retention time of $7.80 \mathrm{~min}$, respectively.
\end{abstract}

Key words: vacuum residue, electromagnetic catalytic cracking (ECC), gas chromatography mass spectrometry (GCMS)

\section{Introduction}

Crude oil is a mixture of organic compounds that consist of hydrocarbon and nonhydrocarbon compounds. It is generated by the fossil material of microorganisms, plants, and animals, which are covered by the past million years. The content of hydrocarbon compounds are more than $90 \%$ and the rest are nonhydrocarbon compounds such as sulphur, nitrogen, oxygen in the different content of volatility, specific gravity, and viscosity [1].

There are large amounts of oil residues in the oil refineries, including atmospheric and vacuum residues, which can be upgraded into valuable light fuels [2]. A vacuum distillation column typically produces $45 \%$ vacuum residue and $54.2 \%$ vacuum gas oil. The atmospheric residue is typically $53 \%$, and vacuum residue is $25 \%$ of crude oil as refinery feed [3]. The vacuum residue resulting from heavy crude oil is 2 to 3 times more than that from medium and light crude oil [4].

The residue of crude oil is generated from a waste product from refinery, which is inexpensive and not maximally used by the industry. In the refinery unit, crude oil is used as feed in the atmospheric distillation column, it produces some oil fractions with the different distance temperature. Light fractions are used as fuel and residue as the heavy fractions have a low selling price [5].

Hydrocarbons are organic compound consist of hydrogen and oxygen. It was one of a contaminant, which can give a bad impact on human and environment. Hydrocarbons were found in crude oil that is used by human in life and potentially stain the environment 6].

The environment can be stained by industrial activity in the refinery, start from downstream until upstream. The exploration includes the geology investigation, seismic, and the drilling to find crude oil sources and in the phase of production, distribution, storage, and trade potentially caused the environmental stain [7].

Industrial pollutants, which came from crude oil potentially endanger organism. This pollutant consist of hydrocarbon aliphatic and aromatic compound, which has light until heavy molecule weight [7].

With increasing consumption of fossil fuels, much effort has been focused on upgrading heavy oils in the recent years. There are large amounts of atmospheric residue (AR) and vacuum-distilled residual (VR) oil in the petroleum refineries that could be transformed into valuable light fuels [8].

There are some technologies, which can be used to upgrading the vacuum residue to produce fuel in the good quality. Moreover, to improve the quality, it can minimize the waste of refinery, which can stain the environment. The negative impact can be decreased. Vacuum residue is a heavy fraction product on the bottom distillation unit in refinery crude oil. Vacuum residue contains $\mathrm{Ni}, \mathrm{V}, \mathrm{N}, \mathrm{S}$, and asphalt. This fraction contains of undesirable compound (some heteroatomic component) such as metal $\mathrm{V}$ and $\mathrm{Ni}$ [9]. 
As heavy fraction product, vacuum residue contains complex compound, such as hydrogen which has high boiling point (above $813 \mathrm{~K}$ ) and heteroatom, 3$5 \%$ sulphur, $0.2-1.0 \%$ nitrogen, and $0.1 \%$ metal. Moreover, vacuum residue which contains undesirable compound such as 5-30\% of asphaltene, rich of polyaromatic and heteroatom, affects the precipitation and coke formation that depend on the reaction condition [10]. Saturates are heavy fraction oil consisting of non-polar hydrocarbon with linear structure, branches, and cyclic which saturate with hydrogen. The higher saturates in the crude oil means the increasing of production heavy fraction oil with higher boiling point [12].

Based on distribution of compound in the refinery unit, vacuum residue has a high boiling point $\left(538^{\circ} \mathrm{C}\right)$ and carbon bond more than 25 . High boiling point is caused by big molecules compound in the vacuum residue. Vacuum residue consists of complex compounds and form big molecules. Bigger molecules makes it hard to be cracked into smaller molecules. Some basic technology, which can be used to upgrade the quality of vacuum residue are thermal cracking, catalytic cracking and hydro cracking [11].

Asphaltene is the most compound, which can be found in vacuum residue. The result from Pertamina RU III Plaju-Sungai Gerong reported that the value/concentration of asphaltene is around $57.5 \%$. Therefore, asphaltene becomes the focus of vacuum residue cracking. Asphaltene contains polyaromatic and heteroatomic compounds with the number of carbon is above 35 . The complex molecules containing in vacuum residue generates a high difficulties in cracking and converting the vacuum residue to a product. Thermal cracking and catalytic cracking are reported to provide the effective processes to crack vacuum residue and catalytic cracking that is consumed a high energy, which is not socio-economically suitable for a largescale process. Ngunyen et al in 2016 is one of formerly researchers who use the temperature condition above $450^{\circ} \mathrm{C}$. It uses high-energy consumption. High temperature indicates the high-energy consumption to process of cracking.

Aromatics are hydrocarbon, which has one or more unsaturated benzene rings, which can be conducted with paraffin or naphtha. Saturates and aromatics are lighter component than asphaltene and naphtha, it can be influence the percentage of light component in crude oil. Resins are polar polyaromatic, which contain heteroatom such as nitrogen, oxygen and sulphur compound. They can be soluble in light alkane such as n-pentane and n-heptane with molecule weight under 1000 g.mol ${ }^{-1}$. Residue which contain high asphaltene and resins are aim to produce cokes [12]. It has been reported that the formation of coke could be less severe in gas phase than that in the liquid phase, because much lower agglomeration reactions occurred in the former status $[13,14]$.

The distillation range of VR is mainly above 500 ${ }^{\circ} \mathrm{C}$, hydrocarbons mainly undergo liquid phase reaction in the existing process. The free radicals which split from hydrocarbon can disperse quickly in the gas phase whereas they are surrounded by surrounding molecules like a "cage" in the liquid phase. Thus, to disperse the formed free radicals, it is necessary to overcome the extra energy barriers spread out from the "cage" in the liquid phase. This is the so-called "radical cage effect" $[15,16]$. Therefore, how to improve the gas-phase reaction ratio and suppress the liquid-phase reaction will become the key problem for the next generation of heavy oil processing technology [17].

Electromagnetics is necessary for achieving electromagnetic compatibility of products, for understanding high-speed digital electronics and wireless, and for optical computer networking. Electrical word describes a broad range of phenomena in addition to electronics, ranging from X-rays to optics to thermal radiation. In physics courses, we are taught that all these phenomena concern electromagnetic waves.

An important concept to aid understanding of electromagnetics is electrical length. Electrical length is a unit less measure that refers to the length of a wire or device at a certain frequency. When the wavelength is much longer than the wire lengths, the basic rules of electronic circuits apply and electromagnetic [18].

To break down the long chain of vacuum residue, we need media or substance, which can weaken the hydrocarbon bond. Every substance has their own magnetic field, and vacuum residue. So, it can be used to weaken the carbon bond in vacuum residue. Thermal vibration cause ion lattice trembles and electron conduction moves. Higher temperature cause the higher metal vibration.

\section{Materials and Method}

Based on Nguyen-Huy (2015), the temperature operation of cracking was $500^{\circ} \mathrm{C}$ and Nguyen-Huy (2016) used 2-4 hours as their reaction time. It gives reference to cracking the vacuum residue with lower temperature and short reaction time than before.

There are some stages to crack by using electromagnetic, catalyst manufacturing, equipment's 
preparation, research, and analyzed. This chart represent the stages of research:

The catalyst is combination from two kind of catalyst to improve catalyst performance in cracking vacuum residue.

Equipment and material preparation

1. Equipment

This cracking process uses equipment series consisting of fixed-bed reactor, thermocouple, band heater, and metal winding as electromagnetic source.

2. Material

Vacuum residue came from Pertamina RU III PlajuSungai Gerong.

Table 2. Characterization of Vacuum Residue(MSDS Pertamina RU III Plaju-Sungai Gerong)

\begin{tabular}{llll}
\hline Uji & Unit & Metode Uji & $\begin{array}{l}\text { Typical } \\
\text { Specification }\end{array}$ \\
\hline Spesific Gravity $60 / 60^{\circ} \mathrm{F}$ & & ASTM D-1298 & Max 0.98 \\
Conradson Carbon Residue & $\% \mathrm{wt}$ & ASTM D-189 & Max 12.5 \\
Vanadium (V) & PPm & AAS & Max 2.0 \\
Sodium (Na) & PPm & AAS & Max 90.0 \\
Pour Point & ${ }^{\circ}$ & ASTM D-97 & Max 120 \\
Sulphur Content & $\% \mathrm{wt}$ & ASTM D-4294 & Max 0.35 \\
Water Content & $\%$ Vol & ASTM D-95 & Max 0.5 \\
Flash Point PMCC & ${ }^{\circ} \mathrm{F}$ & ASTM D-93 & Min 190 \\
Kinematic Viscosity at $170^{\circ} \mathrm{F}$ & $\mathrm{cSt}$ & ASTM D-445 & Max 360.0 \\
Paraffin & $\% \mathrm{wt}$ & & 12.00 \\
Naphtene & $\% \mathrm{wt}$ & & 4.50 \\
Aromatic & $\% \mathrm{wt}$ & & 26.00 \\
Asphaltene & $\% \mathrm{wt}$ & & 57.50 \\
\hline
\end{tabular}

Description of research process

Vacuum residue process uses fixed-bed reactor and the operational condition of electromagnetic catalytic cracking $(\mathrm{ECC})$ on $400^{\circ} \mathrm{C}$ during $75 \mathrm{~min}, 10$ A, and $\mathrm{Fe}_{2} \mathrm{O}_{3} / \mathrm{Al}_{2} \mathrm{O}_{3}$ as catalyst. Catalyst $\mathrm{Fe}_{2} \mathrm{O}_{3} / \mathrm{Al}_{2} \mathrm{O}_{3}$ ratio are 1:5, 1:6, 1:7, 1:8, and 1:9. Ratio catalyst to feed is $3: 100$.

Vacuum residue is introduced into the reactor as much as $1000 \mathrm{~g}$, with the condition $400^{\circ} \mathrm{C}$ during 75 min, and $10 \mathrm{~A}$. Liquid product collected and analyzed the contents by using gas chromatography mass spectrometry (GC-MS).

\subsection{Data Analysis}

Liquid product ECC process were analyzed using GC-MS to detect the compounds contain which have retention time and peak area to explain their compound. In GC-MS, it used scan method. Identified compound of the liquid sample were appropriated with mass spectrometer in GC-MS.

\section{Result and Discussion}

ECC product by using catalyst $\left(\mathrm{Al}_{2} \mathrm{O}_{3} / \mathrm{Fe}_{2} \mathrm{O}_{3}\right)$ ratio $1: 5,1: 6,1: 7,1: 8$, and $1: 9$ produce much liquid product conversion. The highest is $63.5 \%$ by using catalyst ratio 1:9. This results show how much liquid product and the compound contain in it to be used furthermore.

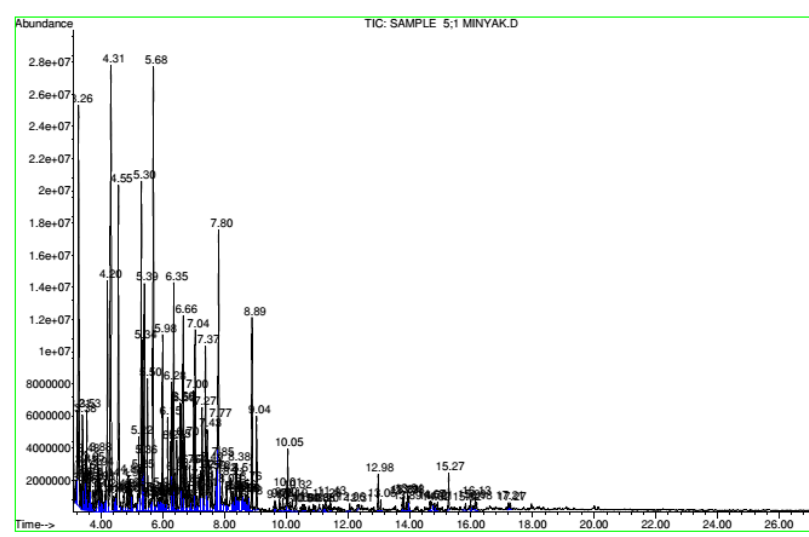

Fig. 5. Chromatogram GC ECC using catalyst $\left(\mathrm{Al}_{2} \mathrm{O}_{3} / \mathrm{Fe}_{2} \mathrm{O}_{3}\right)$ ratio 1:5

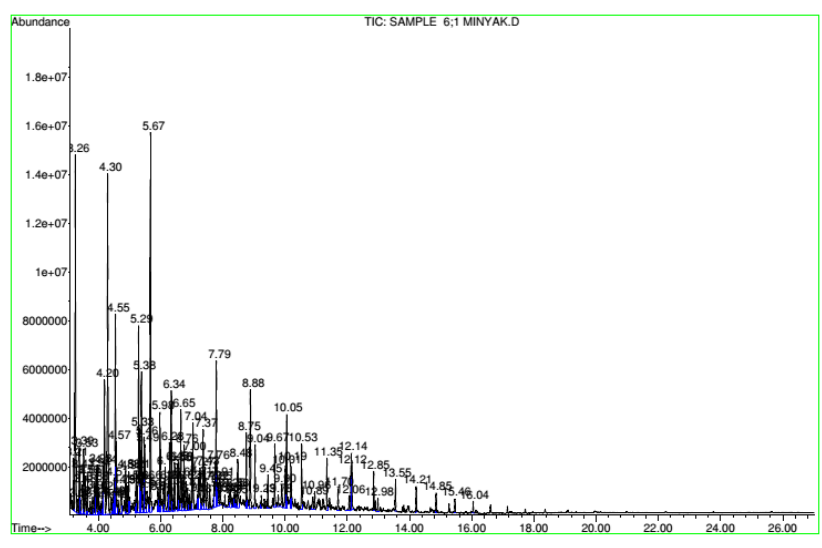

Fig. 6. Chromatogram GC ECC using catalyst $\left(\mathrm{Al}_{2} \mathrm{O}_{3} / \mathrm{Fe}_{2} \mathrm{O}_{3}\right)$ ratio $1: 6$

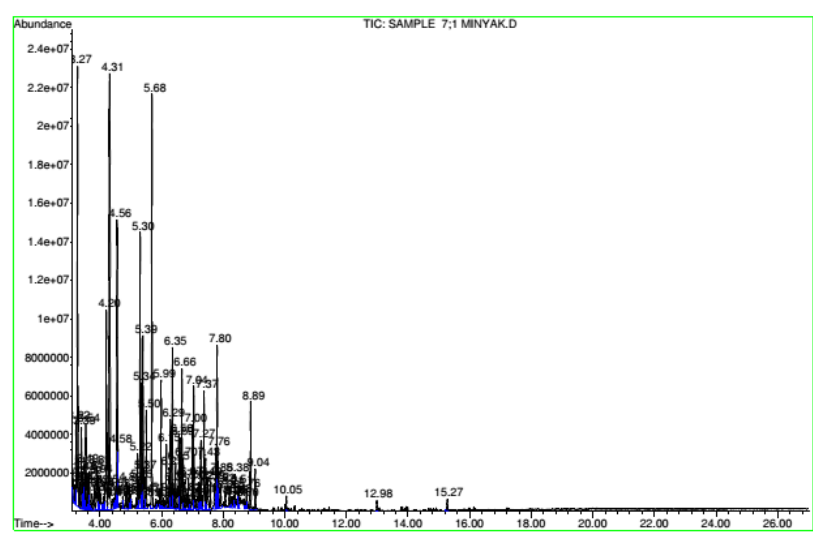

Fig. 7. Chromatogram GC ECC using catalyst $\left(\mathrm{Al}_{2} \mathrm{O}_{3} / \mathrm{Fe}_{2} \mathrm{O}_{3}\right)$ ratio $1: 7$ 


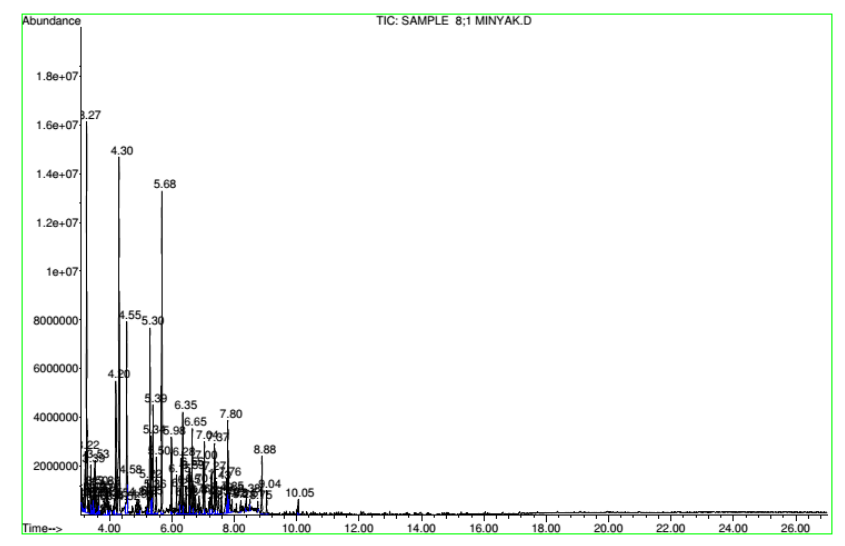

Fig. 8. Chromatogram GC ECC using catalyst $\left(\mathrm{Al}_{2} \mathrm{O}_{3} / \mathrm{Fe}_{2} \mathrm{O}_{3}\right)$ ratio $1: 8$

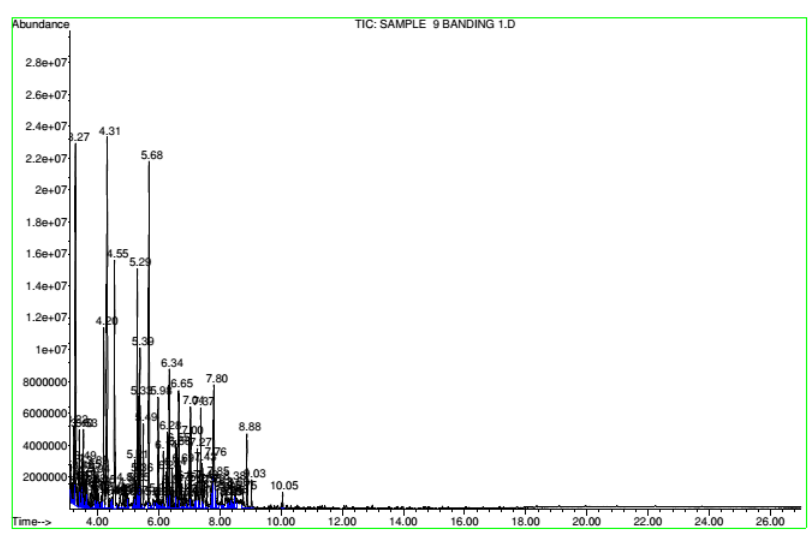

Fig. 9. Chromatogram GC ECC using catalyst $\left(\mathrm{Al}_{2} \mathrm{O}_{3} / \mathrm{Fe}_{2} \mathrm{O}_{3}\right)$ ratio $1: 9$

Table 3. Interpretation of chromatogram GC ECC using catalyst $\left(\mathrm{Al}_{2} \mathrm{O}_{3} / \mathrm{Fe}_{2} \mathrm{O}_{3}\right)$ ratio 1:9

\begin{tabular}{ccc}
\hline $\begin{array}{l}\text { Retention } \\
\text { time }(\mathrm{min})\end{array}$ & content $(\%)$ & Library \\
\hline 3.22 & 1.57 & Heptane,2-methyl- \\
3.27 & 8.6 & Toluene \\
3.4 & 1.17 & Cyclohexane,1,3-dimethyl-,cis- \\
3.54 & 1.32 & Heptane, 2,4-dimethyl- \\
4.30 & 11.38 & p-Xylene \\
4.55 & 5.44 & p-Xylene \\
5.29 & 4.21 & Benzene,1-ethyl-2-methyl- \\
5.33 & 1.74 & Benzene,1-ethyl-2-methyl- \\
5.39 & 2.51 & Benzene,1,3,5-trimethyl- \\
5.49 & 2.51 & Benzene,1,3,5-trimethyl- \\
5.68 & 6.73 & Benzene,1,3,5-trimethyl- \\
5.98 & 1.91 & Benzene,1,2,4-trimethyl- \\
6.28 & 1.30 & Benzene,1-methyl-3-propyl- \\
6.34 & 2.45 & Benzene,2-ethyl-1,4-dimethyl- \\
6.65 & 2.03 & Benzene,1-methyl-3-(1- \\
& & methylethyl)- \\
7.00 & 1.26 & Benzene, 1,2,3,4-tetramethyl- \\
7.04 & 1.7 & Benzene,1,2,3,4-tetramethyl- \\
7.27 & 1.44 & Benzene,2-butenyl- \\
7.37 & 2.30 & Benzene,2-ethenyl-1,4-dimethyl- \\
7.76 & 1.04 & 1H-Indene,2,3-dihydro-1,6- \\
& & dimethyl- \\
7.80 & 3.28 & Naphthalene \\
8.88 & 1.36 & tridecane \\
\hline
\end{tabular}

Based on Table 2, paraffin, olefin, naphthenic and aromatics (PONA) were found in the liquid product
ECC using catalyst $\left(\mathrm{Al}_{2} \mathrm{O}_{3} / \mathrm{Fe}_{2} \mathrm{O}_{3}\right)$ ratio 1:9. PONA compound indicates that asphalting was successfully cracked resulted in the simple compounds. To be more specific, the retention time indicated that $11.38 \%$ of $\mathrm{p}$ xylene, $1.04 \%$ paraffin, $3.28 \%$ naphthenic ware found in retention time of $4.3,7.3$, and $7.80 \mathrm{~min}$, respectively.

The result confirmed that the electromagnetic Catalytic Cracking (ECC) using catalyst $\mathrm{Fe}_{2} \mathrm{O}_{3} / \mathrm{Al}_{2} \mathrm{O}_{3}$ can break complex bound in vacuum residue. In previous research, Khalil (2015), vacuum residue can be cracked in 2-4 hours at $743 \mathrm{~K}$ and 1-2 atm in fixed bed reactor [19].

The formation of 1-alkenes was attributed to the rupture of alkyl free radicals. The formation of isoalkenes was mainly due to the cracking of isomeric alkyl substituents attaching to aromatic rings and naphthenic rings [20]. Meanwhile, he aliphatic free radicals and naphthenic free radicals produced by the cracking reaction could capture $\mathrm{H}$ radicals and then produce alkanes, which is the cause of formation of nalkanes and iso-alkanes and cycloalkanes [21].

The result also proved that the electromagnetic field can break the hydrocarbon bond of vacuum residue, initiated by $\mathrm{Fe}_{2} \mathrm{O}_{3} / \mathrm{Al}_{2} \mathrm{O}_{3} . \mathrm{Fe}_{2} \mathrm{O}_{3}$ has gigged pore than $\mathrm{Al}_{2} \mathrm{O}_{3}$, it makes the compounds with big molecule size can absorb to the pore. Group $\mathrm{OH}^{-}$in $\mathrm{Fe}_{2} \mathrm{O}_{3}$ is a receiver or pulls electron from double bond in saturates bond of vacuum residue. It caused the bond more weak and easy to be cracked.

The electrical conduction mechanism produces heat via electrical resistance. The electrical field of ECC oscillates the electrons or ions in a conductor and leads to an electric current. This current encountered internal resistance, heating the conductor.

Hydrocarbons cracking reactions is well known in an electric arc or electric discharge. In the presence of a Journal Pre-proof 11 catalyst, more valuable products can be formed from free radicals produced in an electric discharge. When the thickness of metal is small compared to the penetration depth, the surface is hot. Under these conditions, electrons are released from the material and are accelerated in the electric field [22]. This electron energy is sufficient to crack the chemical bonds in the molecules constituting free radicals.

$\mathrm{Fe}_{2} \mathrm{O}_{3}$ has big surface area. It can minimize the sintering effect and increase catalytic activity. The combination of $\mathrm{Fe}_{2} \mathrm{O}_{3}$ and $\mathrm{Al}_{2} \mathrm{O}_{3}$ can be more increase catalytic activity and active sites [24].

Nasri [23] told the effect of increased $\mathrm{Fe}$ catalyst on asphaltene reduction is significant at higher amounts of activated carbon (15 and $20 \%)$. With an increase in activated carbon content, the effect of $\mathrm{Fe}$ catalyst on asphaltene reduction has significantly increased. It also can be observed that the reduction of asphaltene is sharp at initial addition of activated carbon and thereafter decreases slowly with increasing activated carbon. 
Hydrocarbon spill on the soil and water would envenom the animals and plants whose life in that environment, not only them but also can envenom the human. Therefore, it has to tackling step on field contamination oil in order to minimize the contamination area. The usage of the waste product of crude oil (VR) by upgrading the quality is the one of the way to minimize the quantity of waste oil.

Result analysis of GC-MS showed that product ECC contain of PONA compound. It can be used as fuel. ECC can upgrade the quality of vacuum residue which known as waste product in refinery. The usage of this product will decrease oil waste, which is harmful for the environment and the life creature in it.

\section{Conclusion}

Process of Electromagnetic Catalytic Cracking (ECC) and catalyst $\mathrm{Fe}_{2} \mathrm{O}_{3} / \mathrm{Al}_{2} \mathrm{O}_{3}$ can crack the complex hydrocarbon bond in vacuum residue faster and being the simple compound. It is PONA compound, which is fuel contents. Catalyst $\left(\mathrm{Al}_{2} \mathrm{O}_{3} / \mathrm{Fe}_{2} \mathrm{O}_{3}\right)$ ratio $1: 9$ give the best result in vacuum residue cracking. It is shown on GC-MS result. In retention time $4.3 \mathrm{~min}$ was found $11.38 \%$ p-xylene which count as aromatic compound. $1.04 \%$ paraffin was found in retention time $7.76 \mathrm{~min}$. Then, 3.28\% naphthenic was found in retention time $7.80 \mathrm{~min}$. The usage of vacuum residue product which is waste refinery product can be reduced the waste and bad effect to environment.

\section{References}

[1] Speight, J.G. "The Chemistry and Technology of Petroleum". 2nd edition. Marcel Dekker, Inc. New York. 1991. Pp 7-10.

[2] M. Hosseinpour, S. Fatemi, and S. J. Ahmadi. "Cracking of petroleum vacuum residue in supercritical water media: Impact of $\alpha-\mathrm{Fe} 2 \mathrm{O} 3$ in the form of free nanoparticles and silica-supported granules". Fuel. 159 (2015) 538-549. Pp : 1-2.

[3] M.C. Medine. "Residue Gasification: An Attractive Bottom of the barrel upgrading technology, New horizons in gasification". The 12th European Gasification Conference, Rotterdam, The Netherlands, March 10-13, 2014. Pp : 6.

[4] A. Kh. Samimi, H. Barijanian, G. Karimi, M. Z. Abianeh. "Selection of the best upgrading processes, for petroleum heavy residues in Iran". Farayandno (in Persian), 41 (2013) 81-98. Pp : 2.

[5] Hartiniati. "Hidrokonversi Katalitik Residu Minyak Bumi: Pengaruh Temperatur Dan Waktu Reaksi”. Pusat Teknologi Pengembangan Sumberdaya Energi, BPPT. 2006. Pp : 4.

[6] Notodarmojo S. "Pencemaran Tanah dan Air Tanah". Institut Teknologi Bandung. Bandung. 2005. Pp : 1-4.

[7] Udiharto. "Aktivitas Mikroba dalam Mendegradasi Minyak". Proccedings Diskusi Ilmiah VII Hasil Penelitian Lemigas. Jakarta : 464-467. 1992.Pp : 15 .
[8] Alboudwarej H, Felix J, Taylor S, Badry R, Bremner C, Brough B. "Highlighting heavy oil". Oilfield Rev 2006;18. Pp: 34-53.

[9] Nguyen-Huy, C., and Eun, W. S. "Oxidative cracking of vacuum residue with steam over $\mathrm{NiK} / \mathrm{CeZr}-\mathrm{Al}$ catalysts". Elsevier, Fuel 192 (2017) 149-157. 2016. Pp : 1-2.

[10] Kim, K.D. and Yong-Kul L. "Active phase of dispersed MoS2 catalysts for slurry phase hydrocracking of vacuum residue". Elsevier, Journal of Catalysis 369 (2019) 111-121. 2018. Pp $: 1-2$.

[11] Gray, Murray R. "Upgrading Petroleum Residue and Heavy Oils", Marcel Dekker Inc., New York. 1994. Pp : 3.

[12] Nguyen-Huy, C., and Eun, W. S. "Amelioration of catalytic activity in steam catalytic cracking of vacuum residue with $\mathrm{ZrO} 2$-impregnated macromesoporous red mud". Elsevier, Fuel 179 (2016) 17-24. 2015. Pp: 2-3.

[13] Bu W, Gray MR. "Kinetics of vapor-phase cracking of bitumen-derived heavy gas oil". Energy Fuels 2013;27:2999-3005. Pp : 2.

[14] Wu G, Katsumura Y, Chihiro Matsuura A, Ishigure $\mathrm{K}$, Kubo J. "Comparison of liquidphase and gasphase pure thermal cracking of n-hexadecane". Ind Eng Chem Res 1996;35:47-54. Pp: 3

[15] Braden DA, Parrack EE, Tyler DR. "Solvent cage effects. I. Effect of radical mass and size on radical cage pair recombination efficiency. II. Is geminate recombination of polar radicals sensitive to solvent polarity". Coord Chem Rev 2001;211:279-94. Pp : 5-7.

[16] Liang WJ. "Heavy Oil Chemistry". Dongying, Shandong, China: China University of Petroleum Press; 2000. Pp: 4.

[17] Che, Yuanjun, Meng Yuana, Yingyun Qiaoa, Qin Liub , Jinhong Zhanga, Yuanyu Tian." Fundamental study of hierarchical millisecond gasphase catalytic cracking process for enhancing the production of light olefins from vacuum residue" . Elsevier, fuel volume 237 (2019) 1-9. Pp : 9.

[18] Schmit, Ron. "Electromagnetic Explained". Handbook for Wireless/Rf, EMC, and High-Speed Electronics. 2002. Pp : 25-47.

[19] Khalil, U. "Robust surface-modified Beta zeolite for selective production of lighter fuels by steamassisted catalytic cracking from heavy oil". Elsevier, Fuel volume 168, 15 Maret 2016. Pp: 6167.

[20] Zeng M, Yuan W, Wang Y, Zhou W, Zhang L, Qi F. "Experimental and kinetic modeling study of pyrolysis and oxidation of n-decane". Combust Flame 2014;161:1701-15. Pp : 4-6.

[21] J.S. Klepfer, T.W. Honeycutt, V. Sharivker, G. Tairova. "Process and Reactor for Microwave Cracking of Plastic Materials". US. Patent 6,184,427, 2001. Pp : 6-7. 
[22] V. Sharivker, T. Honeycutt. "Process for the Desulphurization and Upgrading Fuel Oils". US. Patent 6,797,126, 2004. Pp : 5-7.

[23] Nasri Z, Upgrading Vacuum Distillation "Residue of Oil Refinery using Microwave Irradiation:. Chemical Engineering and Processing - Process Intensification (2019). Pp 15.

[24] Park Y, Kim SK, Pradhan D, Sohn Y. "Surface treatment effects on $\mathrm{CO}$ oxidation reactions over $\mathrm{Co}, \mathrm{Cu}$, and $\mathrm{Ni}$-doped and codoped $\mathrm{CeO}$ catalysts". Chem Eng J 2014;250:25-34. Pp : 8-9. 